\title{
Original Article \\ Screen-based sedentary behaviors, mental health, and social relationships among adolescents
}

\author{
Danilo R Silva ${ }^{{ }^{*}}$, André O Werneck ${ }^{2}$, Crisieli M Tomeleri², Rômulo A Fernandes ${ }^{3}$, Enio RV Ronque ${ }^{2}$, \\ Edilson S Cyrino ${ }^{2}$ \\ ${ }^{1}$ Universidade Federal de Sergipe, São Cristóvão, SE, Brazil; ${ }^{2}$ Universidade Estadual de Londrina, UEL, \\ Londrina, PR, Brazil; ${ }^{3}$ Universidade Estadual Paulista, UNESP, Presidente Prudente, SP, Brazil
}

\begin{abstract}
Aim: To analyze the association between screen-based sedentary behaviors, mental health, and social relationships in Brazilian adolescents. Methods: A representative sample of the adolescents from Londrina/PR was selected ( $\mathrm{n}=1,158 ; 10$ to $17 \mathrm{y}$ ). Weekday and weekend screen time (TV-viewing and computer/video-game), mental health indicators (self-rated health, stress, feelings of sadness, and satisfaction with own body), and perceived social relationships (friends, family, and teachers) were collected through questionnaires. Somatic maturation, body mass index, and physical activity were assessed as covariates. Results: Adolescents who reported higher TV-viewing presented higher odds $(\mathrm{p}<0.05)$ for poor self-rated health (boys), higher stress (both sexes), and dissatisfaction with own body (boys), friendships (girls), and teachers (girls). In contrast, higher computer/video-game use was associated with lower odds $(\mathrm{p}<0.05)$ for poor self-rated health (girls), higher stress (boys), feelings of sadness (both sexes), and dissatisfaction with friends (both sexes) and family (both sexes). Conclusion: While higher TV-viewing is associated with negative outcomes, higher computer/video-game users demonstrate better mental health and lower satisfaction with their social relationships.
\end{abstract}

Keywords: motor activity, physical inactivity; psychological health; interpersonal relations

\section{Introduction}

Beyond well recognized negative effects of physical inactivity, sedentary behavior has been related to several non-communicable diseases ${ }^{1}$. The potential negative effects of sedentary behavior on obesity, hypertension, type 2 diabetes, and even mortality can be independent of physical activity level ${ }^{2}$. However, while biomedical outcomes have been more widely studied, clear evidence on the effects of sedentary behavior on mental health are still lacking ${ }^{3,4}$.

As highlighted in the recent terminology consensus 5 , sedentary behaviors can present several distinct characteristics with specific impacts on health. One of the main current manifestations of sedentary behavior, especially among young people, is screen use, such as TV-viewing, smartphones, computers, or passive video-games. In a relatively short time, infant screen-based media has become an enormous international industry. Data from different parts of the world show alarming screen time use among children and adolescents, from an early age ${ }^{6,7}$. In Brazil, approximately $60 \%$ of the school children in the $9^{\text {th }}$ grade spend more than two hours per day in front of a TV ${ }^{8}$. Additionally, the general screen time level has been increasing among young people and seems to track throughout lifespan ${ }^{9,10}$.

Previous studies suggest that high screen time increases the likelihood of depression, anxiety, and low self-esteem among young people ${ }^{3,11,12}$. It is assumed that media use can influence cognitive aspects, impacting the feelings and social environmental perceptions of young people ${ }^{13}$. However, there are also indications that specific types of screen time can have positive effects on social and mental outcomes ${ }^{14}$.

Thus, in addition to understanding the impacts of different types of screen time, other knowledge gaps persist regarding the relationship between these exposures and mental health indicators, such as the gradual relation (dose-response), differences between sexes ${ }^{15}$, and cultural contexts ${ }^{16}$. In this sense, our aim was to analyze the association between screen time (TV, computer, and video-game), mental health, and social relationships in Brazilian adolescents.

\section{Methods}

\section{Sample}

This is a cross-sectional epidemiological school-based study of Brazilian adolescents aged between 10 and 17 years old, enrolled in public schools of Londrina/PR. Londrina has 506,701 inhabitants, a average human development index of 0.778 , and a gross domestic product per capita of US $\$ 8,530.77^{17}$.

Sample recruitment was performed in two stages. First, all public schools in the city were separated into regions (north, south, east, west, and center) and two schools were randomly selected from each location. Subsequently, classes in the schools 
were randomly selected and all students in these classes (except those using prescription medicine or undergoing treatment for an illness) were invited to participate in the study. Students that failed to return a consent form signed by parents were ineligible. Recruitment peaked at 1,395 adolescents but 237 failed to provide all required data for the analysis of this study and were excluded, reaching a final sample of 1,158 adolescents. Prior to the main data collection, a pilot study was conducted with 90 adolescents (not included in the main analyses), in which questionnaires were performed with a seven day interval to test the reproducibility of the instruments. The local ethics committee approved all the procedures of this study (process number 10655/2012) according to the Declaration of Helsinki.

\section{Screen time}

Adolescents' screen time was accessed through a self-reported questionnaire, which contained four questions asking how many hours a day the adolescent spent watching television and how many hours a day he/she spent using a computer and videogames (PC/VG), on weekdays and weekends. For analyses, screen time was separated into two categories: TV-viewing $(0$ to $2.0 \mathrm{~h} / \mathrm{d}$, 2.1 to $4.0 \mathrm{~h} / \mathrm{d}$ and $>4 \mathrm{~h} / \mathrm{d})$ and $P C / V G$ use $(0 \mathrm{~h} / \mathrm{d}, 0.1$ to $2.0 \mathrm{~h} / \mathrm{d}$, 2.1 to $4.0 \mathrm{~h} / \mathrm{d}$ and $>4 \mathrm{~h} / \mathrm{d})$. Questions presented an intra-class correlation (ICC) between 0.76 and 0.88 .

\section{Perception of social relationships}

Self-perceptions about relationships with friends, family, and teachers were assessed through a questionnaire. Specifically, the questions were organized in a Likert scale (from 1 to 4) and asked: "Regarding your relationship with your classmates and friends, are you”; "Regarding your relationship with your family, are you", and "Regarding your relationship with your professors, are you". Options ranged from very unsatisfied to very satisfied, with four possibilities. The ICCs of the questions were respectively $0.50,0.53$, and 0.69 .

\section{Mental health indicators}

Sadness was collected through the Likert scale type question: "How often do you feel sad or depressed?", options ranged from "very frequently" to "rarely", with four possibilities and an ICC of 0.62. Stress was evaluated through a Likert scale type question: "How often do you feel stressed?", options ranged from "very frequently" to "rarely", with four possibilities and an ICC of 0.80 . Self-rated health was accessed through a self-reported Likert scale type question: "In general, how do you consider your health?:", with four possibilities ranging from "poor" to "excellent" and an ICC of 0.73 . Satisfaction with own body was accessed through a dichotomous (yes or no) question: "Are you satisfied with your body?", with an ICC of 0.87 .

\section{Covariates}

Somatic maturation was estimated through the method of age at peak height velocity ${ }^{18}$, which estimates peak height velocity (PHV) through anthropometric values of stature and trunk-encephalic height. After this, PHV is subtracted from chronological age, creating the age at PHV. Habitual physical activity was estimated through the self-reported Baecke questionnaire ${ }^{19}$, which contemplates sports, leisure, and occupational domains of physical activity. Socioeconomic status (SES) was assessed by means of the Brazilian Criterion for Economic Classification instrument ${ }^{20}$, which considers the education of the household leader and certain possessions, providing a score based on this information.

\section{Statistics procedures}

Descriptive statistics (frequencies, mean, and standard deviation) as well as the chi-square, chi-square for trend, and Mann-Whitney tests were used to describe characteristics and compare groups at baseline. Thereafter, logistic regressions, the reporting odds ratio, and a confidence interval of $95 \%$ (CI95\%), were used to analyze the association between screen time domains and mental health/social relationship variables as well as the association between screen time domains and social/ parental environment. All analyses were conducted using SPSS 22.0 software, with a significance level of $5 \%$.

\section{Results}

Table 1 presents the characteristics of the sample. In general, boys were older and presented greater time of VG/PC use. On the other hand, girls presented higher rates of being stressed, sad, and dissatisfied with their body. 
Table 1. Characteristics of the sample according to gender (Londrina 2011, Brazil; $n=1,158$ ).

\begin{tabular}{|c|c|c|c|}
\hline & Boys & Girls & p-value \\
\hline Age (y) & $13.1 \pm 1.6$ & $12.8 \pm 1.5$ & 0.030 \\
\hline SES $(\%)$ & & & 0.290 \\
\hline Lowest & 65.0 & 68.3 & \\
\hline Highest & 35.0 & 31.7 & \\
\hline BMI $\left(\mathrm{kg} / \mathrm{m}^{2}\right)$ & $19.7 \pm 3.9$ & $19.9 \pm 4.1$ & 0.332 \\
\hline TV viewing in week $\left(\mathrm{h} / \mathrm{d}^{-1}\right)$ & $3.5(3.5)$ & $3.9(3.0)$ & 0.278 \\
\hline TV viewing at weekend $\left(\mathrm{h} / \mathrm{d}^{-1}\right)$ & $3.7(4.0)$ & $3.5(4.0)$ & 0.223 \\
\hline VG/PC use in week $\left(\mathrm{h} / \mathrm{d}^{-1}\right)$ & $3.0(3.8)$ & $2.0(3.4)$ & $<0.001$ \\
\hline VG/PC use at weekend $\left(\mathrm{h} / \mathrm{d}^{-1}\right)$ & $3.1(5.0)$ & $2.3(5.0)$ & $<0.001$ \\
\hline Health perception (\%) & & & $<0.001$ \\
\hline $\mathrm{Bad}$ & 1.6 & 2.6 & \\
\hline Regular & 17.0 & 21.4 & \\
\hline Good & 46.3 & 54.2 & \\
\hline Excellent & 35.0 & 21.9 & \\
\hline Feeling stressed (\%) & & & $<0.001$ \\
\hline Rarely & 17.7 & 8.6 & \\
\hline Sometimes & 50.7 & 39.6 & \\
\hline Usually & 21.1 & 33.3 & \\
\hline Always & 10.5 & 18.5 & \\
\hline Sadness $(\%)$ & & & $<0.001$ \\
\hline Rarely & 15.4 & 4.9 & \\
\hline Sometimes & 58.6 & 52.2 & \\
\hline Usually & 20.5 & 31.9 & \\
\hline Always & 5.6 & 11.0 & \\
\hline Satisfaction with body (\%) & & & $<0.001$ \\
\hline Yes & 66.0 & 51.9 & \\
\hline No & 34.0 & 48.1 & \\
\hline Satisfaction with family (\%) & & & 0.002 \\
\hline Very satisfied & 59.5 & 49.6 & \\
\hline Satisfied & 30.2 & 37.2 & \\
\hline Dissatisfied & 7.2 & 9.3 & \\
\hline Very dissatisfied & 3.1 & 3.9 & \\
\hline Satisfaction with friendship (\%) & & & 0.105 \\
\hline Very satisfied & 43.1 & 40.9 & \\
\hline Satisfied & 48.7 & 47.5 & \\
\hline Dissatisfied & 6.3 & 8.9 & \\
\hline Very dissatisfied & 2.0 & 2.7 & \\
\hline Satisfaction with teachers (\%) & & & 0.533 \\
\hline Very satisfied & 18.1 & 17.9 & \\
\hline Satisfied & 44.0 & 45.0 & \\
\hline Dissatisfied & 23.6 & 25.3 & \\
\hline Very dissatisfied & 14.3 & 11.8 & \\
\hline
\end{tabular}

Note. $\mathrm{SES}=$ socioeconomic status; $\mathrm{BMI}=$ body mass index $; \mathrm{VG} / \mathrm{PC}=$ video game and/or personal computer.

Prevalence of TV-viewing and VG/PC use according to sex are presented in figure 1 . In both sexes, the prevalence of watching more than 4 hours of TV was greater than $40 \%$. For
VG/PC use, the prevalence of more than 4 hours was around $25 \%$ in both sexes. 
Figure 1. Distribution of sedentary behavior contexts in Brazilian adolescents.
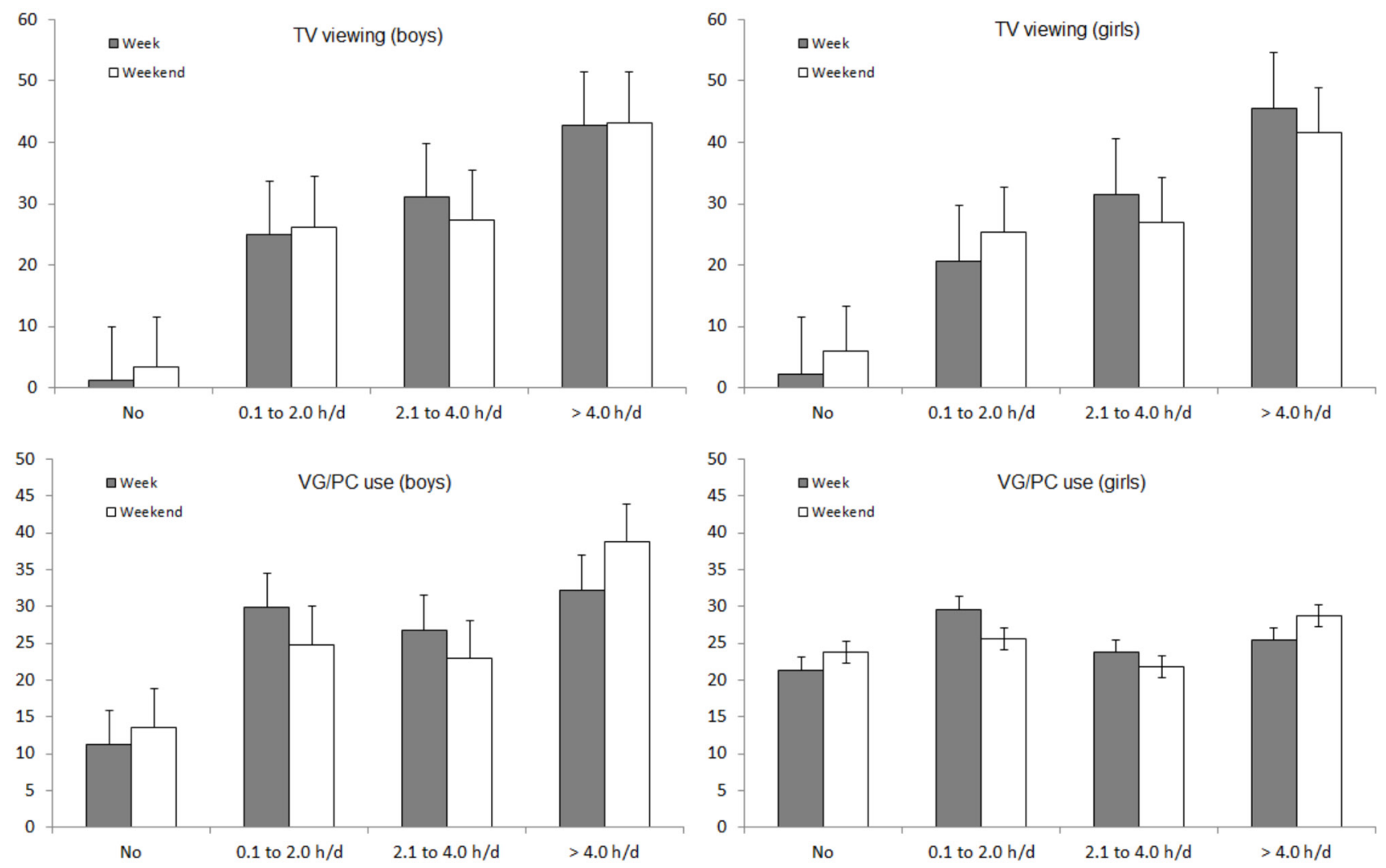

Note. $\mathrm{VG} / \mathrm{PC}=$ video game and/or personal computer

Table 2 presents the association of screen time patterns with social relationships and mental health indicators among boys. In general, TV viewing was positively associated with poor self-rated health (weekend), higher stress (weekdays), and dissatisfaction with body (both weekdays and weekend). On the other hand, VG/PC use was inversely related to higher perception of stress (weekend), higher sadness (weekdays), dissatisfaction with relationships with family and friends (both weekdays and weekend). However, for half of these associations, reduced odds were observed only from 2 to $4 \mathrm{~h} / \mathrm{d}$ of exposure.

Table 2. Association between sedentary behavior contexts and indicators of mental health and social relationships in boys (Londrina 2011, Brazil; $\mathrm{n}=605$ ).

\begin{tabular}{|c|c|c|c|c|c|c|c|}
\hline & \multirow{3}{*}{$\begin{array}{c}\text { Poor health } \\
\text { OR } \\
\text { (CI 95\%) }\end{array}$} & \multirow{3}{*}{$\begin{array}{c}\text { Stressed } \\
\text { OR } \\
\text { (CI 95\%) }\end{array}$} & \multirow{3}{*}{$\begin{array}{l}\text { Sadness } \\
\text { OR } \\
\text { (CI 95\%) }\end{array}$} & \multicolumn{4}{|c|}{ Dissatisfied } \\
\hline & & & & with body & with family & with friendship & with teachers \\
\hline & & & & $\begin{array}{c}\text { OR } \\
\text { (CI 95\%) }\end{array}$ & $\begin{array}{c}\text { OR } \\
\text { (CI 95\%) }\end{array}$ & $\begin{array}{c}\text { OR } \\
\text { (CI 95\%) }\end{array}$ & $\begin{array}{c}\text { OR } \\
\text { (CI 95\%) }\end{array}$ \\
\hline \multicolumn{8}{|c|}{ TV viewing in week } \\
\hline 0 to $2.0 \mathrm{~h} / \mathrm{d}$ & 1 & 1 & 1 & 1 & 1 & 1 & 1 \\
\hline 2.1 to $4.0 \mathrm{~h} / \mathrm{d}$ & $\begin{array}{l}1.05 \\
(0.57 \text { to } 1.92)\end{array}$ & $\begin{array}{l}1.17 \\
(0.71 \text { to } 1.96)\end{array}$ & $\begin{array}{l}1.65 \\
(0.98 \text { to } 2.78)\end{array}$ & $\begin{array}{l}1.07 \\
(0.64 \text { to } 1.82)\end{array}$ & $\begin{array}{l}0.74 \\
(0.35 \text { to } 1.62)\end{array}$ & $\begin{array}{l}1.50 \\
(0.64 \text { to } 3.54)\end{array}$ & $\begin{array}{l}0.81 \\
(0.51 \text { to } 1.29)\end{array}$ \\
\hline$>4.0 \mathrm{~h} / \mathrm{d}$ & $\begin{array}{l}1.46 \\
(0.84 \text { to } 2.53)\end{array}$ & $\begin{array}{l}2.25 \\
(\mathbf{1 . 4 1} \text { to } 3.58)\end{array}$ & $\begin{array}{l}1.43 \\
(0.87 \text { to } 2.36)\end{array}$ & $\begin{array}{l}2.40 \\
(1.48 \text { to } 3.88)\end{array}$ & $\begin{array}{l}1.04 \\
(0.52 \text { to } 2.08)\end{array}$ & $\begin{array}{l}1.37 \\
(0.60 \text { to } 3.15)\end{array}$ & $\begin{array}{l}1.38 \\
(0.90 \text { to } 2.13)\end{array}$ \\
\hline \multicolumn{8}{|c|}{ TV viewing at weekend } \\
\hline 0 to $2.0 \mathrm{~h} / \mathrm{d}$ & 1 & 1 & 1 & 1 & 1 & 1 & 1 \\
\hline 2.1 to $4.0 \mathrm{~h} / \mathrm{d}$ & $\begin{array}{l}2.07 \\
(1.12 \text { to } 3.84)\end{array}$ & $\begin{array}{l}1.11 \\
\text { (0.68 to } 1.82)\end{array}$ & $\begin{array}{l}0.74 \\
(0.45 \text { to } 1.24)\end{array}$ & $\begin{array}{l}1.91 \\
(1.14 \text { to } 3.22)\end{array}$ & $\begin{array}{l}0.53 \\
(0.24 \text { to } 1.18)\end{array}$ & $\begin{array}{l}0.74 \\
(0.34 \text { to } 1.62)\end{array}$ & $\begin{array}{l}0.86 \\
(0.55 \text { to } 1.37)\end{array}$ \\
\hline$>4.0 \mathrm{~h} / \mathrm{d}$ & $\begin{array}{l}\mathbf{1 . 8 6} \\
\mathbf{( 1 . 0 5} \text { to } 3.31)\end{array}$ & $\begin{array}{l}1.49 \\
(0.97 \text { to } 2.32)\end{array}$ & $\begin{array}{l}0.85 \\
(0.54 \text { to } 1.34)\end{array}$ & $\begin{array}{l}2.27 \\
(1.42 \text { to } 3.65)\end{array}$ & $\begin{array}{l}0.82 \\
(0.43 \text { to } 1.57)\end{array}$ & $\begin{array}{l}0.58 \\
(0.28 \text { to } 1.22)\end{array}$ & $\begin{array}{l}0.90 \\
(0.60 \text { to } 1.36)\end{array}$ \\
\hline
\end{tabular}




\begin{tabular}{|c|c|c|c|c|c|c|c|}
\hline & \multirow[b]{2}{*}{$\begin{array}{c}\text { Poor health } \\
\text { OR } \\
\text { (CI 95\%) }\end{array}$} & \multirow[b]{2}{*}{$\begin{array}{c}\text { Stressed } \\
\text { OR } \\
\text { (CI 95\%) }\end{array}$} & \multirow[b]{2}{*}{$\begin{array}{c}\text { Sadness } \\
\text { OR } \\
\text { (CI 95\%) }\end{array}$} & \multicolumn{4}{|c|}{ Dissatisfied } \\
\hline & & & & $\begin{array}{l}\text { with body } \\
\text { OR } \\
\text { (CI 95\%) } \\
\end{array}$ & $\begin{array}{c}\text { with family } \\
\text { OR } \\
\text { (CI 95\%) }\end{array}$ & $\begin{array}{c}\text { with friendship } \\
\text { OR } \\
\text { (CI 95\%) }\end{array}$ & $\begin{array}{c}\text { with teachers } \\
\text { OR } \\
\text { (CI 95\%) }\end{array}$ \\
\hline \multicolumn{8}{|c|}{$\mathrm{VG} / \mathrm{PC}$ use in week } \\
\hline No & 1 & 1 & 1 & 1 & 1 & 1 & 1 \\
\hline 0.1 to $2.0 \mathrm{~h} / \mathrm{d}$ & $\begin{array}{l}0.98 \\
(0.44 \text { to } 2.20)\end{array}$ & $\begin{array}{l}0.60 \\
(0.33 \text { to } 1.11)\end{array}$ & $\begin{array}{l}\mathbf{0 . 3 0} \\
(\mathbf{0 . 1 6} \text { to } 0.56)\end{array}$ & $\begin{array}{l}1.04 \\
(0.53 \text { to } 2.05)\end{array}$ & $\begin{array}{l}\mathbf{0 . 1 6} \\
(0.06 \text { to } 0.40)\end{array}$ & $\begin{array}{l}\mathbf{0 . 2 7} \\
\text { (0.10 to } 0.69)\end{array}$ & $\begin{array}{l}1.05 \\
(0.57 \text { to } 1.94)\end{array}$ \\
\hline 2.1 to $4.0 \mathrm{~h} / \mathrm{d}$ & $\begin{array}{l}0.87 \\
(0.38 \text { to } 1.97)\end{array}$ & $\begin{array}{l}0.63 \\
(0.34 \text { to } 1.18)\end{array}$ & $\begin{array}{l}\mathbf{0 . 3 9} \\
(\mathbf{0 . 2 1} \text { to } 0.72)\end{array}$ & $\begin{array}{l}1.08 \\
(0.55 \text { to } 2.14)\end{array}$ & $\begin{array}{l}\mathbf{0 . 3 4} \\
(\mathbf{0 . 1 5} \text { to } 0.75)\end{array}$ & $\begin{array}{l}\mathbf{0 . 1 5} \\
(0.05 \text { to } 0.45)\end{array}$ & $\begin{array}{l}1.04 \\
\text { (0.56 to } 1.93)\end{array}$ \\
\hline$>4.0 \mathrm{~h} / \mathrm{d}$ & $\begin{array}{l}1.62 \\
(0.75 \text { to } 3.48)\end{array}$ & $\begin{array}{l}0.87 \\
(0.48 \text { to } 1.59)\end{array}$ & $\begin{array}{l}0.47 \\
(0.26 \text { to } 0.86)\end{array}$ & $\begin{array}{l}1.32 \\
(0.68 \text { to } 2.57)\end{array}$ & $\begin{array}{l}\mathbf{0 . 3 0} \\
(\mathbf{0 . 1 4} \text { to } 0.64)\end{array}$ & $\begin{array}{l}0.55 \\
(0.25 \text { to } 1.25)\end{array}$ & $\begin{array}{l}1.45 \\
(0.79 \text { to } 2.65)\end{array}$ \\
\hline \multicolumn{8}{|c|}{$\mathrm{VG} / \mathrm{PC}$ use at weekend } \\
\hline No & 1 & 1 & 1 & 1 & 1 & 1 & 1 \\
\hline 0.1 to $2.0 \mathrm{~h} / \mathrm{d}$ & $\begin{array}{l}0.99 \\
(0.49 \text { to } 2.03)\end{array}$ & $\begin{array}{l}\mathbf{0 . 5 4} \\
(\mathbf{0 . 3 0} \text { to } 0.98)\end{array}$ & $\begin{array}{l}0.36 \\
(0.19 \text { to } 0.69)\end{array}$ & $\begin{array}{l}1.04 \\
(0.55 \text { to } 1.96)\end{array}$ & $\begin{array}{l}0.26 \\
(0.11 \text { to } 0.63)\end{array}$ & $\begin{array}{l}0.60 \\
(0.24 \text { to } 1.48)\end{array}$ & $\begin{array}{l}1.05 \\
(0.59 \text { to } 1.88)\end{array}$ \\
\hline 2.1 to $4.0 \mathrm{~h} / \mathrm{d}$ & $\begin{array}{l}1.07 \\
(0.52 \text { to } 2.21)\end{array}$ & $\begin{array}{l}\mathbf{0 . 5 4} \\
(\mathbf{0 . 3 0} \text { to } 0.99)\end{array}$ & $\begin{array}{l}0.39 \\
(0.20 \text { to } 0.74)\end{array}$ & $\begin{array}{l}0.99 \\
(0.52 \text { to } 1.89)\end{array}$ & $\begin{array}{l}\mathbf{0 . 3 4} \\
(\mathbf{0 . 1 5} \text { to } 0.80)\end{array}$ & $\begin{array}{l}\mathbf{0 . 3 3} \\
(\mathbf{0 . 1 1} \text { to } 0.94)\end{array}$ & $\begin{array}{l}0.64 \\
(0.35 \text { to } 1.17)\end{array}$ \\
\hline$>4.0 \mathrm{~h} / \mathrm{d}$ & $\begin{array}{l}0.77 \\
(0.39 \text { to } 1.52)\end{array}$ & $\begin{array}{l}0.74 \\
(0.43 \text { to } 1.26)\end{array}$ & $\begin{array}{l}0.78 \\
(0.45 \text { to } 1.35)\end{array}$ & $\begin{array}{l}1.19 \\
(0.66 \text { to } 2.16)\end{array}$ & $\begin{array}{l}\mathbf{0 . 3 1} \\
(\mathbf{0 . 1 5} \text { to } \mathbf{0 . 6 6 )}\end{array}$ & $\begin{array}{l}0.51 \\
(0.22 \text { to } 1.20)\end{array}$ & $\begin{array}{l}1.21 \\
\text { ( } 0.71 \text { to } 2.08)\end{array}$ \\
\hline
\end{tabular}

Note. $\mathrm{VG} / \mathrm{PC}=$ video game and/or personal computer. All models are adjusted for chronological age, somatic maturity, BMI, and physical activity.

The associations between screen time patterns, social relationships, and mental health among girls are presented in table 3 . Similarly to the boys, TV-viewing was positively associated with higher stress (weekdays) and dissatisfaction with relationships with friends (weekend) and teachers (weekdays), while VG/PC use was negatively related to poor self-rated health (both weekdays and weekend), higher sadness (weekdays), and dissatisfaction with relationships with family and friends (both weekdays and weekend). Except for self-rated health and relationships with friends, reduced odds were observed at lower or moderate levels of $\mathrm{VG} / \mathrm{PC}$, only.

Table 3. Association between sedentary behavior contexts and indicators of mental health and social relationships in girls (Londrina 2011, Brazil; $\mathrm{n}=737$ ).

\begin{tabular}{|c|c|c|c|c|c|c|c|}
\hline & \multirow[b]{2}{*}{$\begin{array}{c}\text { Poor health } \\
\text { OR } \\
\text { (CI 95\%) }\end{array}$} & \multirow[b]{2}{*}{$\begin{array}{c}\text { Stressed } \\
\text { OR } \\
\text { (CI 95\%) }\end{array}$} & \multirow[b]{2}{*}{$\begin{array}{c}\text { Sadness } \\
\text { OR } \\
\text { (CI 95\%) }\end{array}$} & \multicolumn{4}{|c|}{ Dissatisfied } \\
\hline & & & & $\begin{array}{l}\text { with body } \\
\text { OR } \\
\text { (CI 95\%) }\end{array}$ & $\begin{array}{c}\text { with family } \\
\text { OR } \\
\text { (CI 95\%) }\end{array}$ & $\begin{array}{c}\text { with friendship } \\
\text { OR } \\
\text { (CI 95\%) }\end{array}$ & $\begin{array}{c}\text { with teachers } \\
\text { OR } \\
\text { (CI 95\%) }\end{array}$ \\
\hline \multicolumn{8}{|c|}{ TV viewing in week } \\
\hline 0 to $2.0 \mathrm{~h} / \mathrm{d}$ & 1 & 1 & 1 & 1 & 1 & 1 & 1 \\
\hline 2.1 to $4.0 \mathrm{~h} / \mathrm{d}$ & $\begin{array}{l}0.84 \\
(0.52 \text { to } 1.38)\end{array}$ & $\begin{array}{l}1.20 \\
(0.79 \text { to } 1.83)\end{array}$ & $\begin{array}{l}0.96 \\
(0.63 \text { to } 1.47)\end{array}$ & $\begin{array}{l}1.18 \\
(0.77 \text { to } 1.82)\end{array}$ & $\begin{array}{l}0.60 \\
(0.32 \text { to } 1.11)\end{array}$ & $\begin{array}{l}0.67 \\
(0.36 \text { to } 1,26)\end{array}$ & $\begin{array}{l}1.54 \\
(0.99 \text { to } 2.41)\end{array}$ \\
\hline$>4.0 \mathrm{~h} / \mathrm{d}$ & $\begin{array}{l}1.08 \\
(0.70 \text { to } 1.69)\end{array}$ & $\begin{array}{l}1.52 \\
(1.03 \text { to } 2.24)\end{array}$ & $\begin{array}{l}1.09 \\
(0.74 \text { to } 1.61)\end{array}$ & $\begin{array}{l}1.07 \\
(0.72 \text { to } 1.59)\end{array}$ & $\begin{array}{l}0.74 \\
(0.43 \text { to } 1.28)\end{array}$ & $\begin{array}{l}0.71 \\
(0.40 \text { to } 1.25)\end{array}$ & $\begin{array}{l}1.58 \\
(1.04 \text { to } 3.28)\end{array}$ \\
\hline \multicolumn{8}{|c|}{ TV viewing at weekend } \\
\hline 0 to $2.0 \mathrm{~h} / \mathrm{d}$ & 1 & 1 & 1 & 1 & 1 & 1 & 1 \\
\hline 2.1 to $4.0 \mathrm{~h} / \mathrm{d}$ & $\begin{array}{l}1.12 \\
(0.69 \text { to } 1.81)\end{array}$ & $\begin{array}{l}0.86 \\
(0.58 \text { to } 1.28)\end{array}$ & $\begin{array}{l}0.86 \\
(0.58 \text { to } 1.30)\end{array}$ & $\begin{array}{l}0.97 \\
(0.64 \text { to } 1.48)\end{array}$ & $\begin{array}{l}1.02 \\
(0.57 \text { to } 1.80)\end{array}$ & $\begin{array}{l}\text { 1.96 } \\
\text { (1.04 to } 3.69)\end{array}$ & $\begin{array}{l}0.77 \\
(0.51 \text { to } 1.17)\end{array}$ \\
\hline$>4.0 \mathrm{~h} / \mathrm{d}$ & $\begin{array}{l}1.44 \\
(0.94 \text { to } 2.20)\end{array}$ & $\begin{array}{l}0.96 \\
(0.67 \text { to } 1.38)\end{array}$ & $\begin{array}{l}1.16 \\
(0.81 \text { to } 1.66)\end{array}$ & $\begin{array}{l}1.19 \\
(0.82 \text { to } 1.73)\end{array}$ & $\begin{array}{l}0.67 \\
(0.39 \text { to } 1.16)\end{array}$ & $\begin{array}{l}1.38 \\
(0.75 \text { to } 2.53)\end{array}$ & $\begin{array}{l}0.95 \\
(0.66 \text { to } 1.37)\end{array}$ \\
\hline \multicolumn{8}{|c|}{ VG/PC use in week } \\
\hline No & 1 & 1 & 1 & 1 & 1 & 1 & 1 \\
\hline 0.1 to $2.0 \mathrm{~h} / \mathrm{d}$ & $\begin{array}{l}\mathbf{0 . 4 8} \\
(\mathbf{0 . 3 0} \text { to } 0.79)\end{array}$ & $\begin{array}{l}0.69 \\
(0.45 \text { to } 1.06)\end{array}$ & $\begin{array}{l}\mathbf{0 . 6 4} \\
(0.41 \text { to } 0.99)\end{array}$ & $\begin{array}{l}1.13 \\
(0.72 \text { to } 1.76)\end{array}$ & $\begin{array}{l}\mathbf{0 . 4 3} \\
(\mathbf{0 . 2 2} \text { to } 0.83)\end{array}$ & $\begin{array}{l}\mathbf{0 . 3 9} \\
(\mathbf{0 . 2 1} \text { to } 0.74)\end{array}$ & $\begin{array}{l}0.50 \\
(0.32 \text { to } 0.80)\end{array}$ \\
\hline 2.1 to $4.0 \mathrm{~h} / \mathrm{d}$ & $\begin{array}{l}\mathbf{0 . 5 7} \\
(\mathbf{0 . 3 5} \text { to } 0.95)\end{array}$ & $\begin{array}{l}1.12 \\
(0.72 \text { to } 1.76)\end{array}$ & $\begin{array}{l}0.90 \\
(0.57 \text { to } 1.42)\end{array}$ & $\begin{array}{l}1.02 \\
(0.63 \text { to } 1.63)\end{array}$ & $\begin{array}{l}\mathbf{0 . 4 7} \\
(\mathbf{0 . 2 4} \text { to } 0.93)\end{array}$ & $\begin{array}{l}\mathbf{0 . 4 2} \\
(\mathbf{0 . 2 2} \text { to } 0.80)\end{array}$ & $\begin{array}{l}1.04 \\
\text { (0.66 to } 1.64)\end{array}$ \\
\hline$>4.0 \mathrm{~h} / \mathrm{d}$ & $\begin{array}{l}0.61 \\
(0.37 \text { to } 0.99)\end{array}$ & $\begin{array}{l}1.13 \\
(0.72 \text { to } 1.76)\end{array}$ & $\begin{array}{l}1.20 \\
(0.77 \text { to } 1.87)\end{array}$ & $\begin{array}{l}1.11 \\
(0.69 \text { to } 1.76)\end{array}$ & $\begin{array}{l}0.77 \\
(0.42 \text { to } 1.42)\end{array}$ & $\begin{array}{l}\mathbf{0 . 3 0} \\
(\mathbf{0 . 1 5} \text { to } 0.61)\end{array}$ & $\begin{array}{l}0.90 \\
(0.57 \text { to } 1.41)\end{array}$ \\
\hline
\end{tabular}




\begin{tabular}{|c|c|c|c|c|c|c|c|}
\hline & \multirow{3}{*}{$\begin{array}{c}\text { Poor health } \\
\text { OR } \\
\text { (CI 95\%) }\end{array}$} & \multirow{3}{*}{$\begin{array}{c}\text { Stressed } \\
\text { OR } \\
\text { (CI 95\%) }\end{array}$} & \multirow{3}{*}{$\begin{array}{c}\text { Sadness } \\
\text { OR } \\
\text { (CI 95\%) }\end{array}$} & \multicolumn{4}{|c|}{ Dissatisfied } \\
\hline & & & & with body & with family & with friendship & with teachers \\
\hline & & & & $\begin{array}{c}\text { OR } \\
\text { (CI 95\%) }\end{array}$ & $\begin{array}{c}\text { OR } \\
\text { (CI 95\%) }\end{array}$ & $\begin{array}{c}\text { OR } \\
\text { (CI 95\%) }\end{array}$ & $\begin{array}{c}\text { OR } \\
\text { (CI 95\%) }\end{array}$ \\
\hline \multicolumn{8}{|c|}{ VG/PC use at weekend } \\
\hline No & 1 & 1 & 1 & 1 & 1 & 1 & 1 \\
\hline 0.1 to $2.0 \mathrm{~h} / \mathrm{d}$ & $\begin{array}{l}0.50 \\
(0.30 \text { to } 0.82)\end{array}$ & $\begin{array}{l}0.70 \\
(0.45 \text { to } 1.07)\end{array}$ & $\begin{array}{l}1.17 \\
(0.75 \text { to } 1.81)\end{array}$ & $\begin{array}{l}1.01 \\
(0.64 \text { to } 1.57)\end{array}$ & $\begin{array}{l}0.55 \\
(0.29 \text { to } 1.03)\end{array}$ & $\begin{array}{l}\mathbf{0 . 4 7} \\
(\mathbf{0 . 2 5} \text { to } 0.87)\end{array}$ & $\begin{array}{l}0.85 \\
(0.54 \text { to } 1.32)\end{array}$ \\
\hline 2.1 to $4.0 \mathrm{~h} / \mathrm{d}$ & $\begin{array}{l}0.72 \\
(0.44 \text { to } 1.19)\end{array}$ & $\begin{array}{l}0.80 \\
(0.51 \text { to } 1.25)\end{array}$ & $\begin{array}{l}1.16 \\
(0.74 \text { to } 1.83)\end{array}$ & $\begin{array}{l}1.03 \\
(0.64 \text { to } 1.64)\end{array}$ & $\begin{array}{l}\mathbf{0 . 3 9} \\
(\mathbf{0 . 1 9} \text { to } 0.81)\end{array}$ & $\begin{array}{l}0.43 \\
(0.22 \text { to } 0.84)\end{array}$ & $\begin{array}{l}0.65 \\
(0.40 \text { to } 1.05)\end{array}$ \\
\hline$>4.0 \mathrm{~h} / \mathrm{d}$ & $\begin{array}{l}0.76 \\
(0.48 \text { to } 1.22)\end{array}$ & $\begin{array}{l}0.95 \\
(0.63 \text { to } 1.45)\end{array}$ & $\begin{array}{l}1.21 \\
\text { (0.79 to } 1.85)\end{array}$ & $\begin{array}{l}1.16 \\
(0.75 \text { to } 1.80)\end{array}$ & $\begin{array}{l}0.67 \\
(0.37 \text { to } 1.21)\end{array}$ & $\begin{array}{l}\mathbf{0 . 3 1} \\
(\mathbf{0 . 1 6} \text { to } 0.61)\end{array}$ & $\begin{array}{l}1.15 \\
\text { (0.75 to } 1.77)\end{array}$ \\
\hline
\end{tabular}

Note. $\mathrm{VG} / \mathrm{PC}=$ video game and/or personal computer. All models are adjusted for chronological age, somatic maturity, BMI, and physical activity.

\section{Discussion}

The purpose of this study was to evaluate the association between screen-based sedentary behaviors, mental health, and perceived social relationships among adolescents. We found that, in both sexes, adolescents with higher TV-viewing demonstrated poorer self-rated health (boys), higher stress (habit on weekdays), and greater dissatisfaction with own body (boys) and social relationships (girls). On the other hand, those who reported higher VG/PC use presented better self-rated health (girls), lower feelings of sadness (habit on weekdays; only moderate use in girls), and higher satisfaction with family and friends relationships.

Physical inactivity is well recognized as a risk factor for cardiovascular health as well as mental health among adolescents ${ }^{21,22}$. However, sedentary behavior emerged in the area of human kinetics as distinct risk factor for cardiovascular health ${ }^{23-25}$. Studies conducted with adolescents have already demonstrated positive relationships of screen time, especially TV-viewing, with dyslipidemia and other risk factors such as hypertension and fasting glucose ${ }^{26,27}$. More recently, mental health has been receiving attention from early ages, given its influence on the prevalence of mental disorders among adults ${ }^{28}$, which represents a current global challenge ${ }^{29}$.

Our findings showed that, regardless of age, maturation, physical activity, and BMI, higher TV viewing during the week was positively associated with stress in both sexes, and poor self-rated health and dissatisfaction with body among boys. A possible mechanism could be through commercials exhibiting extremely artificial and ideal body images, which can induce adolescents to think that their body is not attractive ${ }^{30,31}$. A similar hypothesis can also cause stress ${ }^{31}$. In addition, having a TV in the bedroom has been pointed out as a risk factor for sleep deprivation, which can mediate the relationship between screen time and health outcomes ${ }^{32}$.

Moderate and high TV viewing were, respectively, associated with dissatisfaction with relationships with friends (habit on weekend) and teachers (habit on weekdays) among girls. The time spent watching TV can compromise time with friends ${ }^{33}$ and doing school homework ${ }^{34}$. High TV time has been related to poor academic achievement through different pathways ${ }^{35}$, a fact that could affect students' perception of teachers. The isolation caused by screen-based sedentary behaviors could also be a mediator in the relation between TV viewing and stress in both sexes ${ }^{36}$, which is related to depressive symptoms ${ }^{4}$, higher risk of poor social behavior, and disengagement in school ${ }^{37}$.

Interestingly, $\mathrm{PC} / \mathrm{VG}$ use was a "protection factor" for stress (habit on weekend for boys), feelings of sadness (habit on weekdays only), and dissatisfaction with family and friends for both sexes; and for poor self-rated health among girls. The relation between $\mathrm{PC} / \mathrm{VG}$ time and health is unclear. There are indications of negative effects ${ }^{38}$, however this relationship seems to vary according to the characteristics of the use and type of game ${ }^{39}$. Thus, it is possible to reduce stress and improve other mental health outcomes playing videogames ${ }^{40}$, given that through PC/VG use, adolescents can socialize with their peers 39. Future research should investigate the contexts in which these behaviors occur. Co-viewing TV, and using the computer or playing video games with friends and parents can influence their psychological effects ${ }^{13}$.

Our findings build upon information about the potential overall effects of screen-based sedentary behaviors on health. However, several questions remain to be answered. In the present study, although some insights into gradual association were gained, we had low sensibility to this end, and objective measures of sedentary behaviors in different contexts should elucidate the specific dose-response between screen time and outcomes. In addition, the co-occurrence of these behaviors, specific phase of manifestation (e.g., critical window of neurological development) ${ }^{41}$, and their interaction with other correlates of mental health, such as family history/structure and physical/social environment, should be investigated.

Considering alarming levels of sedentary behaviors worldwide, we corroborate that not all sedentary behaviors are equal. Among the screen-based behaviors, TV viewing has been more related to negative cardiovascular health compared to $\mathrm{PC} /$ $\mathrm{VG}^{27}$, which we extend to mental health. Interestingly, while prevalence of TV viewing declined, PC/VG use increased among Brazilian young people between 2001 and $2011^{42}$. Although more studies are warranted, the above information could help in the formulation of specific interventions to reduce sedentary behaviors, beginning with the most harmful. Interventions based on physical environment have been showing promising results 43,44 . 
Our study presents limitations that have to be mentioned. Firstly, our indicator of sedentary behavior only contemplates screen-based sedentary behavior and is subjective, despite our aim to analyze separate domains. Furthermore, due to our study design (cross-sectional), we cannot pinpoint causality. For example, a bidirectional relationship was proposed between screen time and mental health ${ }^{45}$. On the other hand, we adjusted analyses by body mass index, somatic maturation, and physical activity, which are important correlates of mental health ${ }^{46,47}$. As a first threshold of "risk", we adopted the internationally recommended cutoff for young people $(2 \mathrm{~h} / \mathrm{d})^{48}$, followed by another cutoff widely used in the literature $(4 \mathrm{~h} / \mathrm{d})^{4}$, which also allowed the understanding of gradual relationships. Moreover, within a growing research field, we presented data of screenbased sedentary behaviors, mental health, and social relationship perceptions of more than a thousand adolescents of a middle income country.

Thus, we conclude that TV-viewing is associated with poor mental health (e.g. stress, sadness, and dissatisfaction with own body) and perception of poor social relationships. On the other hand, PC/VG use is associated with good mental health indicators and better social relationships.

\section{Informed consent}

Informed consent was obtained from all individual participants and the parents of the adolescents included in the study.

\section{References}

1. Rezende LFM, Sá TH, Mielke GI, Viscondi JYK, Rey-López JP, Garcia LMT. All-Cause Mortality Attributable to Sitting Time: Analysis of 54 Countries Worldwide. Am J Prev Med. 2016;51(2):253-63.

2. Biswas A, Oh PI, Faulkner GE, Bajaj RR, Silver MA, Mitchell MS, et al. Sedentary time and its association with risk for disease incidence, mortality, and hospitalization in adults a systematic review and meta-analysis. Ann Intern Med. 2015;162(2):123-32.

3. Carson V, Hunter S, Kuzik N, Gray CE, Poitras VJ, Chaput J, et al. Systematic review of sedentary behaviour and health indicators in school-aged children and youth: an update 1. Appl Physiol Nutr Metab. 2016;41(6 (Suppl. 3)):S240-S265.

4. Hoare E, Milton K, Foster C, Allender S. The associations between sedentary behaviour and mental health among adolescents: a systematic review. Int J Behav Nutr Phys Act. 2016;13(1):108.

5. Tremblay MS, Aubert S, Barnes JD, Saunders TJ, Carson V, Latimer-Cheung AE, et al. Sedentary behavior research network (SBRN) - Terminology consensus project process and outcome. Int J Behav Nutr Phys Act. 2017;14:75.

6. IBGE. Pesquisa Nacional de Saúde do Escolar - PeNSE. 2015 1-132 p.

7. Christakis, DA. The effects of infant media usage: what do we know and what should we learn? Acta Paediatr. 2009; 98(1):8-16.

8. Hinkley T, Verbestel V, Ahrens W, Lissner L, Molnar D, Moreno LA, et al. Early childhood electronic media use as a predictor of poorer well-being: a prospective cohort study. JAMA Pediatr. 2014;168(5): 485-92.

9. Hesketh K, Wake M, Graham M, Waters E. Stability of television viewing and electronic game / computer use in a prospective cohort study of Australian children : relationship with body mass index. Int J Behav Nutr Phys Act. 2007;4:60.

10. Biddle SJH, Pearson N, Ross GM, Braithwaite R. Tracking of sedentary behaviours of young people : A systematic review. Prev Med. 2010;51(5):345-51.

11. Biddle SJH, Asare M. Physical activity and mental health in children and adolescents: a review of reviews. Br J Sports Med. 2011;45(11):886-95.

12. Costigan SA, Barnett L, Plotnikoff RC, Lubans DR. The health indicators associated with screen-based sedentary behavior among adolescent girls: a systematic review. J Adolesc Health. 2013;52(4):382-92.

13. Kirkorian HL, Wartellar EA, Anderson DR. Media and young children's learning. Futur Child. 2008;18(1):39-61.

14. Barr-Anderson DJ, Sisson SB. Media use and sedentary behavior in adolescents: what do we know, what has been done, and where do we go? Adolesc Med State Art Rev. 2012;23(3):511-28.

15. Busch V, Manders LA, de Leeuw JR. Screen time associated with health behaviors and outcomes in adolescents. Am J Health Behav. 2013;37(6):819-30.

16. Iannotti RJ, Janssen I, Haug E, Kololo H, Annaheim B, Borraccino A, et al. Interrelationships of adolescent physical activity, screenbased sedentary behaviour, and social and psychological health. Int J Public Health. 2009;54(SUPPL. 2):191-8.

17. Instituto Brasileiro de Geografia e Estatística - IBGE. Censo 2010. 2010.

18. Mirwald RL, Baxter-Jones ADG, Bailey DA, Beunen GP. An assessment of maturity from anthropometric measurements. Med Sci Sports Exerc. 2002;34(4):689-694.

19. Baecke J, Burema J, Frijters J. A short questionanaire for the measuremnet of habitual physical activity in epidemiological studies. Am J Clin. 1982;36(November):936-42.

20. ABEP - Associacao Brasileira de Empresas de Pesquisa. Criério de Classificação Econômica Brasil. 2010.

21. Spruit A, Assink M, van Vugt E, van der Put C, Stams GJ. The effects of physical activity interventions on psychosocial outcomes in adolescents: A meta-analytic review. Clin Psychol Rev. 2016;45:56-71.

22. Ekelund U, Anderssen S a., Froberg K, Sardinha LB, Andersen LB, Brage S. Independent associations of physical activity and cardiorespiratory fitness with metabolic risk factors in children: The European youth heart study. Diabetologia. 2007;50(9):1832-40.

23. Van-de- Ploeg HP, Chey T, Korda RJ, Banks E, Bauman A. Sitting Time and All-Cause Mortality Risk in 222497 Australian Adults. Arch Intern Med. 2012;172(6):494-500.

24. Dunstan DW, Barr ELM, Healy GN, Salmon J, Shaw JE, Balkau B. Television viewing time and mortality: The australian diabetes, obesity and lifestyle study (ausdiab). Circulation. 2010;121(3):384-91.

25. Dunstan DW, Thorp AA, Healy GN. Prolonged sitting: is it a distinct coronary heart disease risk factor? Curr Opin Cardiol. 2011;26:412-9. 
26. Martínez-Gómez D, Eisenmann JC, Gómez-Martínez S, Veses A, Marcos A, Veiga OL. Sedentary behavior, adiposity and cardiovascular risk factors in adolescents. The AFINOS study. Rev Esp Cardiol. 2010;63(3):277-85.

27. Byun W, Dowda M, Pate RR. Associations between screen-based sedentary behavior and cardiovascular disease risk factors in Korean youth. J Korean Med Sci. 2012;27(4):388-94.

28. Primack BA, Swanier B, Georgiopoulos AM, Land SR, Fine MJ. Association between media use in adolescence and depression in young adulthood. Arch Gen Psychiatry. 2015;66(2):181-8.

29. Baxter AJ, Patton G, Scott KM, Degenhardt L, Whiteford HA. Global Epidemiology of Mental Disorders: What Are We Missing? PLoS One. 2013;8(6):1-9.

30. Añez E, Fornieles-Deu A, Fauquet-Ars J, López-Guimerà G, PuntíVidal J, Sánchez-Carracedo D. Body image dissatisfaction, physical activity and screen-time in Spanish adolescents. J Health Psychol. 2016. Epub ahead of print, doi: 10.1177/1359105316664134.

31. Dakanalis A, Clerici M, Caslini M, Favagrossa L, Prunas A, Volpato $\mathrm{C}$, et al. Internalization of sociocultural standards of beauty and disordered eating behaviours: The role of body surveillance, shame and social anxiety. J Psychopathol. 2014;20(1):33-7.

32. Barlett ND, Gentile DA, Barlett CP, Eisenmann JC, Walsh DA. Sleep as a Mediator of Screen Time Effects on US Children's Health Outcomes. J Child Media. 2012;6(1):37-50.

33. Richards R, McGee R, Williams SM, Welch D, Hancox RJ. Adolescent screen time and attachment to parents and peers. Arch Pediatr Adolesc Med. 2010;164(3):258-62.

34. Aguilar MM, Vergara FA, Velásquez EJA, Marina R, GarcíaHermoso A. Screen time impairs the relationship between physical fitness and academic attainment in children. J Pediatr (Rio J) 2015;91(4):339-45.

35. García-Hermoso A, Martínez-Vizcaíno V, Recio-Rodriguez JI, Díez-Fernandes A, Gómez-Marcos MA, García-Ortiz L, et al. Abdominal obesity as a mediator of the influence of physical activity on insulin resistance in Spanish adults. Prev Med (Baltim) 2016; 82: 59-64.

36. McHale SM, Crouter AC, Tucker CJ. Free-Time Activities in Middle Childhood: Links with Adjustment in Early Adolescence. Child Dev. 2001;72(6):1764-78.

37. Sisson SB, Broyles ST, Newton RL, Baker BL, Chernausek SD. TVs in the bedrooms of children : Does it impact health and behavior? Prev Med. 2011;52(2):104-8.

38. Maras D, Flament MF, Murray M, Buchholz A, Henderson KA, Obeid N. Screen time is associated with depression and anxiety in Canadian youth. Prev Med. 2015;73:133-8.

39. Granic I, Lobel A, E CM, Engels RCME. The benefits of playing video games. Am. Psychol. 2014;69(1):66-78.

40. Russoniello C V., O'brien K, Parks JM. EEG, HRV and Psychological Correlates while Playing Bejeweled II: A Randomized Controlled Study. Annu Rev CyberTherapy Telemed. 2009;7(1):189-92.

41. Lagercrantz H. Connecting the brain of the child from synapses to screen-based activity. Acta Paediatr. 2016;105(4):352-7.

42. Silva KS, Da Silva Lopes A, Dumith SC, Garcia LMT, Bezerra J, Nahas MV. Changes in television viewing and computers/ videogames use among high school students in Southern Brazil between 2001 and 2011. Int J Public Health. 2014;59(1):77-86.
43. Maitland C, Stratton G, Foster S, Braham R, Rosenberg M. A place for play? The influence of the home physical environment on children 's physical activity and sedentary behaviour. Int J Behav Nutr Phys Act. 2013;10(1):1.

44. Kopcakova J, Veselska ZD, Geckova AM, Bucksch J, Nalecz $\mathrm{H}$, Sigmundova D. Is a perceived activity-friendly environment associated with more physical activity and fewer screen-based activities in adolescents? Int J Environ Res Public Health. 2017;14(1):1-8.

45. Gunnell KE, Flament MF, Buchholz A, Henderson KA, Obeid $\mathrm{N}$, Schubert N, et al. Examining the bidirectional relationship between physical activity, screen time, and symptoms of anxiety and depression over time during adolescence. Prev Med. 2016;88:147-52.

46. Marsh S, Foley LS, Wilks DC, Maddison R. Family-based interventions for reducing sedentary time in youth: A systematic review of randomized controlled trials. Obes Rev. 2014;15(2):117-33.

47. Gunnell KE, Flament MF, Buchholz A, Henderson KA, Obeid $\mathrm{N}$, Schubert N. Examining the bidirectional relationship between physical activity, screen time, and symptoms of anxiety and depression over time during adolescence. Prev Med. 2016;88:147-52.

48. American Academy of Pediatrics. Committee on Public Education. American Academy of Pediatrics: Children, adolescents, and television. Pediatrics 2001;107(2):423-6.

\section{Acknowledgements}

This work was supported by the Brazilian -Council of Scientific and Technological Development (grant number: 483867/2009-8).

The authors thank the school administrators, in which the study was conducted, for allowing the researchers to conduct observations, and the young people who took part in this investigation. The authors also thank Décio Barbosa, Alessandra Okino, Jair Oliveira, Danielle Venturini, Mariana Carnelossi, and Sandra Kawaguti for their substantial contributions to the research, including assistance in data collection and entry. This study was funded by the National Council of Scientific and Technological Development (CNPq/Brazil-Process 483867/2009-8). ERVR, ESC, and RAF were supported by grants from CNPq/ Brazil. DRS (sandwich doctorate scholarship - process 201022/2015-0) and AOW (scientific initiation) are also supported by CNPq.

\section{Corresponding author}

*Danilo Rodrigues Pereira da Silva

Universidade Federal de Sergipe. Departamento de Educação Física. Avenida Marechal Rondon, s/n - Rosa Elze, São Cristóvão - SE, Brazil.

Email: danilorpsilva@gmail.com

Manuscript received on June 29, 2017

Manuscript accepted on September 14, 2017

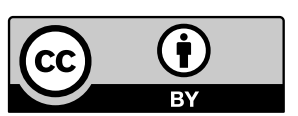

Motriz. The Journal of Physical Education. UNESP. Rio Claro, SP, Brazil - eISSN: 1980-6574 - under a license Creative Commons - Version 3.0 